\title{
Adult education: an approach for use in consumer education programmes
}

\section{Cisca Green}

\begin{abstract}
OPSOMMING
Hierdie artikel is ' $n$ poging tot die samestelling van 'n gekategoriseerde, maar geïntegreerde lys van beginsels wat tydens verbruikersonderrig gevolg kan word. Die lys word as 'n samevatting van die beginsels soos in die bestudeerde literatuur aangetref, voorgehou om as vertrekpunt te dien tydens die ontwerp van volwasse leeraktiwiteite in 'n bepaalde situasie. Die lys is gekategoriseer volgens die eienskappe van die volwasse leerder, die leersituasie en die leerproses. Die grondslag van die konsep 'volwasse leer' is as uitgangspunt geneem, naamlik die behavioristiese benadering, kognitiewe teorieë, beginsels van humanisme, sosiale leerteorie en konstruktivisme. Teorieë spesifiek op volwasse leer gefokus, word uitgesonder. Hierdie teorieë word volgens Merriam en Caffarella (1991:249) onderverdeel in dié met die oog op die eienskappe van volwassenes, dié wat die volwassene se lewensituasie beklemtoon en dié wat rondom veranderinge in die bewuste sentreer. Hierdie drie kategorieë is breedweg na die konsepte 'eienskappe van die volwasse leerder', 'leersituasie' en 'leerproses' herlei, wat deurgaans in hierdie artikel geld. Verskillende teorieë binne elk van hierdie kategorieë is verder bespreek.
\end{abstract}

Mrs F Green

Department of Consumer Science, University of Pretoria

\section{THE AIM OF THE ARTICLE}

The first aim of the article is to briefly review learning and adult learning theories and to try to link adult learning theories to the basic learning theories. The second aim is to look at general principles applicable to adult education practice and to trace these principles to learning and adult learning theories. These principles, based on learning and adult learning theories, can then be used as guidelines for planning and conducting adult education programmes for consumers.

\section{ADULT EDUCATION}

Before the particular foundations of adult education can be discussed, agreement is required what the concept of 'adult education' entails. Within the context of adult education, an adult can be viewed from a psychological perspective, defining it as when a person 'arrives at a self-concept' of being responsible for his own life, and of being self-directing (Knowles, 1991:570). It is, however, difficult to pinpoint this exact moment. The adult concept can also be viewed as socially constructed, referring to the extent in which the adult fulfils social roles that are typically assigned to adults in a society (Gravett, 2001:6). Although a generic adult learner does not exist, some characteristics of adults can be identified that will allow educators of adult consumers to consider them as a group. These typical characteristics will find their place as part of the principles for adult education proposed within this article.

\section{THEORETICAL FOUNDATIONS}

'A good theory should provide both explanations of phenomena and guidelines for action. But theories about human behavior also carry with them assumptions about human nature, the purpose of education, and desirable values. The better you understand the various theories, therefore the better decisions you will be able to make regarding learning experiences that will achieve the ends you wish to achieve' (Knowles, 1990:2).

A theory should provide a conceptual framework for interpreting examples of adult learning as it is observed. It should also direct attention to possible solutions for problems experienced in the particular field of adult education (Merriam \& Caffarella, 1991:125). The notion of 'adult education' would be easy to explain if there was a single theory that differentiates 
adults from children; that included all types of learning; and that was at once easy and simple to interpret (Merriam \& Caffarella, 1991:125). Yet, there is no such theory. There are, however, many theories useful in improving our understanding of adult education. Most of these theories focus on learning, or teaching or both aspects of education. The emphasis of this article will be on the theories of learning as it is assumed that the principles of these theories will contribute not only to understanding how adults learn, but also how to construct and facilitate the learning process.

The particular theories included in this discussion are those that were found in the literature under review. It is not the intention with this article to critique any theory but merely to make use of it in its original form.

\section{BASIC LEARNING THEORIES}

Learning can be thought of as a process by which behavior changes as a result of experiences' (Maples \& Webster,1980 in Merriam \& Caffarella, 1991:124).

There are many explanations of learning, which are often called theories. There is, however, little consensus on how many learning theories there exactly are or how these theories should be grouped together. From the literature it seems that five particular orientations or perspectives are distinguished that give insights into learning in adulthood. These are the behaviouristic approach of Thorndike, Pavlov, Watson, Guthrie, Hull, Tolman, and Skinner; cognitive theories of Koffka, Kohler, Lewin, Piaget, Ausubel, Bruner, Gagne and Tolman; the principles of humanism (from Maslow, Rogers, Knowles), the social learning theory as mentioned by Bandura and Rotter and constructivism described by Dewey, Montessori, Piaget, Bruner and Vygotsky.

Behaviourism, in short, is based on three underlying assumptions about the process of learning. Observable (overt) behaviour rather than internal thought processes is the focus of study - learning is therefore manifested by a change in behaviour. Secondly, what a learner internalizes is determined by elements in the environment and not within the individual learner himself. The principles of contingency and reinforcement form the third assumption. The former referring to 'how close in time two events must be for a bond to be formed' and the latter to 'any means of increasing the likelihood that an event will be repeated' (Merriam \& Caffarella, 1991:126, 137).

The cognitive orientation proposes that the human mind is not simply a passive exchange-terminal system where the stimuli arrive and the appropriate response leaves. Rather, the thinking person interprets sensations and gives meaning to the events that impinge upon his consciousness' (Grippen \& Peters in Merriam \& Caffarella, 1991:129). The individual, with emphasis on the mental processes of the individual as a learner, is the main focus of cognitive-orientated learning theories.
Humanist theories consider learning from the perspective of the human potential for growth. The emphasis is on a person's experience, the freedom and responsibility he possesses in order to grow to his full capacity. Learning is seen as a function of motivation and involves choice and responsibility (Rogers, 1983 in Jones, 1988:152; Maslow, 1970 in Merriam \& Caffarella, 1991:132, 137).

Social learning theory postulates that people learn from observing other people within social settings. Observational learning is further influenced by the four processes of attention, retention (memory), rehearsal and motivation. Social learning theories contribute to adult learning by highlighting the importance of social context and explicating the processes of modelling and mentoring (Merriam \& Caffarella, 1991:139).

Another contemporary perspective on learning, not previously seen as one of the basic learning theories, is constructivism. This concept rests on the assumption that learning is a process of creating meaning or knowledge (Gravett, 2001:18; Gagnon \& Collay; 2002, Merriam \& Caffarella, 1999:264). Within this particular perception, learning per se is defined as an active process of constructing meaning and transforming' understandings in interaction with the environment'. New learning is constructed through the learner's existing knowledge that serves as an interpretative framework. A learner's existing knowledge thus, plays a very important role in understanding new information.

The construction of meaning can be an individual process but is very often also a social process. This leads to constructing of new knowledge through interaction and collaboration with other people. This aspect of constructivism, called specifically social constructivism, relates closely to social learning theories. Learning is viewed as a movement from the external to the internal, wherein 'thought is mediated by social interaction' (Houser \& Vaughan in Gravett, 2001:20). Language and social interaction are considered the most important mediators of this process of internalization.

For the purpose of this article, these brief descriptions of the five orientations of learning will suffice. For further reference these theories are summarized in Table 1 .

Despite agreement on this classification system for basic learning theories, no single orientation for adult learning predominates (Maehl, 2000:33). Certain theories focusing specifically on learning in adulthood can however, be identified. Although not clearly expounded in the literature as such, the theories to be discussed in the next section will correspond with the basic principles of one of the five orientations as referred to earlier. This particular linkage will be indicated throughout the following discussion. 


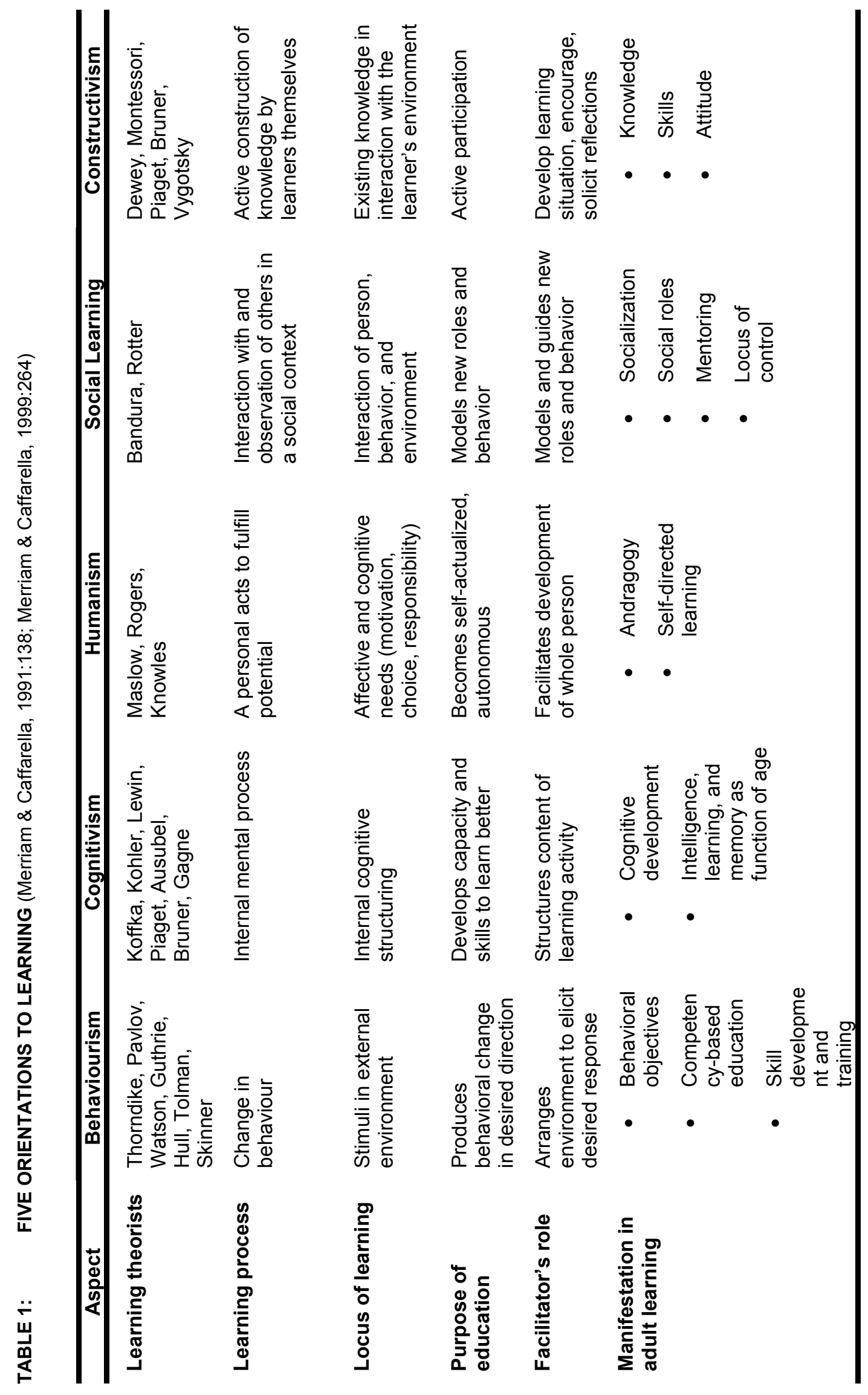




\section{THEORIES ABOUT ADULT LEARNING}

This discussion presents theory-building efforts that purport to explain learning in adulthood. Merriam and Caffarella (1991:249) organized the theories according to those that focus on adult characteristics, those that emphasize an adult's life situation, and those that centre on changes in consciousness. These three categories can broadly be linked to the concepts of 'adult learner', 'learning situation' and 'learning process', which will apply throughout this article. Different theories within each of these categories will receive further attention.

\section{The adult learner}

Physical and psychological dimensions of the adult are discussed here. The theories of Knowles, Cross and Knox were studied when focusing on these characteristics of the adult learners.

Knowles in particular, based his theory of andragogy on six assumptions, which can all be seen as characteristics of the adult learner. He defined his theory as 'the art and science of helping adults learn' and claimed that these assumptions are a 'set of wellgrounded principles of good practice' (Knowles, 1980:40-59; Knowles, 1990:58-63). These assumptions and their specific implications for adult education practice are worthy of note. A brief description of each assumption will be looked at first, followed by the implications for adult consumer education programmes.

The first assumption states adults have 'the need to know'. Adults have to know why they have to learn before undertaking to learn. They have to be informed about the benefits they will gain from learning as well as the negative consequences of not learning (Knowles, 1990:58).

The learner's 'self-concept' is the second assumption mentioned by Knowles. It is postulated that once matured adults derive a self-concept, they will develop a need to be seen and treated as being capable of selfdirection.

Knowles' third assumption gives attention to 'the role of the learner's experience'. Adults approach learning activities with experiences that differ in quality as well as quantity.

'Readiness to learn', the fourth assumption, states that developmental tasks associated with moving from one developmental stage to the next, is a way to indicate readiness to learn.

The fifth assumption is 'orientation to learning'. It is said that adults are life-centered in their orientation to learning. Adults are motivated to learn if they perceive that it will help them perform certain tasks or deal with problems that they are confronted with in real life situations.
'Motivation', the sixth and last assumption by Knowles states that while it is correct that adults are responsive to some external motivators, the most potent motivators to participate in learning activities seem to be internal pressures such as a desire for job-satisfaction, self-esteem and to improve quality of life (Knowles, 1990:63).

The loci of learning within the humanistic framework are the affective and cognitive needs of adults, including aspects such as motivation, choice and responsibility. Knowles' theory clearly fits in with the humanistic orientation to learning.

Cross (1981) offers another attempt at theory-building based on adult characteristics. Her theory is also referred to as the CAL model (Characteristics of Adults as Learners). This theory consists of two classes of variables, namely personal and situational characteristics. personal characteristics include physical, psychological and socio-cultural dimensions whereas the situational characteristics refer to aspects of part-time versus full-time learning as well as voluntary and compulsory learning (Cross, 1981: 235; Merriam \& Caffarella, 1991:252). No other relevant works by Cross were retrieved from the literature and therefore receive no further attention in this article. The main principles of her theory, however, do feature within the other cited frameworks.

The core of Knox's proficiency theory (1980) is the notion of a discrepancy between the current and the desired level of proficiency. Knox defined 'proficiency' as the 'capability to perform satisfactory if given the opportunity'. This performance appears to involve some combination of knowledge, skills, and attitudes. The concept apparently also helps to explain adult motivation and achievement in learning situations (Merriam \& Caffarella, 1991:255). Motivation and achievement as such are mentioned as basic human needs and this theory can therefore be categorized as having a humanistic orientation to learning.

\section{The learning situation}

The learning situation, as intended in this article, is set in an adult's life situation concerning the learner's roles and responsibilities. It also includes the context in which learning will take place. The focus will be on the theories of McClusky and Jarvis.

McClusky (1963, in Merriam \& Caffarella, 1991:255) named his theory the 'margin of life' which refers to a reserve of energy required to deal with a particular learning situation. This required energy is derived from the energy a person is left with after the energy available to deal with the 'load of life' has been used. $\mathrm{He}$ argued that his theory helps to explain the dynamics of adult learning. According to Merriam and Caffarella (1991:255), McClusky's theory does not directly address learning itself, but rather when learning is most likely to happen and will therefore not receive further attention in this article. 
Another theory discussed by Merriam and Caffarella (1991:256) is that by Jarvis (1987). He states that all learning begins with experience and all experience occurs within a social context. Jarvis's theory holds that learning commences when a person enters into a social situation in which a potential learning experience may occur. The theory pertinently situates learning within a social context, stating that learning is an interactive phenomenon and not an isolated internal process.

Although Jarvis's theory does mention the experience of the learner (where this theory then fits into the category of the adult learner), it also focuses very specifically on the responses of the learner and the social aspects of adult learning, making it also appropriate to the learning process. This theory pertains to definite aspects of a humanistic as well as a social learning orientation to learning and can be applied by educators to understand adult learners better as well as when facilitating the learning process.

\section{The learning process}

Adult learning can be described from a cognitive perspective, which specifically deals with the mental construct of meaning. The learning process, however, is not only an individual activity but also involves social interaction. The social aspects of learning are therefore included within this particular category. The best-known theories in this field are those of Mezirow and Freire.

Mezirow's notion of 'perspective transformation' $(1977,1981,1989,1990)$ is defined as the 'process of becoming critically aware of how and why our presuppositions have come to control the way we perceive, understand and feel our world' (Mezirow, 1990 in Merriam \& Caffarella, 1991:259). This theory deals with the adult's interest in self-knowledge and insights gained through reflection. Mezirow defines learning as 'the social process of using prior interpretation to construe and appropriate a new or revised interpretation or meaning of one's experience in order to guide future action' (Gravett, 2001:23; Jones, 1988: 154). The underlying principles of social learning theories are clearly to be seen.

Freire's theory (1970, in Merriam \& Caffarella, 1991:262) for social change distinguishes between 'knowledge-banks' and problem-posing education. In traditional 'banking education', deposits of knowledge are made into the learner's mind, whereas in problem-posing the facilitators and learners cooperate in a dialogue that seeks to humanize and liberate. Central to learning is a changed relationship between the facilitator and learner. Dialogue is the method by which sharing of information takes place and by which consciousness is raised. The ultimate goal seems to be liberation (or praxis), which is the 'action and reflection of men upon their world in order to transform it' (Merriam \& Caffarella, 1991:262). Freire's theory incorporates aspects of both humanism and social learning theory. It also touches on critical theory de- scribing the role of the facilitator so as to understand and to become a part of the learner's culture, to stimulate learning, and hence to empower the individual learner (Cranton, 1989:6).

\section{PRINCIPLES OF ADULT LEARNING}

Most of the theorists and authors on adult education seem to try to identify principles that can be applied to practising adult education, summarizing what has been learned from research or observed in practice. Brookfield (1988:27-29) reported on the earlier attempts made by Gibb (1960), Miller (1964), Kidd (1973) and Knox (1977). The assumptions of Knowles (1980) are also a good example of a set of principles about adult learners that have implications for practice. Others have similar, often more advanced lists, for example Brundage and Mackeracker (1980) who identified 36 learning principles (Brookfield, 1988:27-29). Darkenwald and Merriam (1982) present a list of eight principles derived from learning process research. All these principles were summarized by Brookfield (1988:31) as follows, in the sense that:

- Adults learn throughout their lives, with the negotiations of the transitional stages in the life-span being the immediate causes and motives for learning

- Adults exhibit diverse learning styles - strategies for coding information, cognitive procedures, mental sets, and learn in different ways, at different times, for different purposes

- Adults like learning activities to be problem-centred and to be meaningful to their life situation

- Adults want the learning outcomes to have some immediacy of application

- Current learning is affected by past experiences, serving as an enhancement or hindrance

- Self-concept is linked to effective learning

- Adults exhibit a tendency toward self-directedness in their learning.

Merriam and Caffarella (1991:302) questioned the usefulness of a set of principles for guiding research or practice. Learning in adulthood is embedded in its context and a single set of principles is not likely to hold truth for the wide-ranging diversity of learners in learning situations. Nonetheless, until an integrated theory with its derived principles on adult education is established, a generic set of principles can be useful to guide adult education activities.

The compiled set of principles, as represented in Tables $2-4$, was derived from the different theoretical foundations in the literature. If a stated principle could not be traced to the original theory, it was not included in the constructed list. This list is intended to be a synopsis of the principles proposed in the literature. It can also be used as a guideline to follow when consumer education is practised and serves as the point of departure to construct a conceptual framework for the designing of adult learning activities in a particular setting. The list is categorized, for continuation pur- 


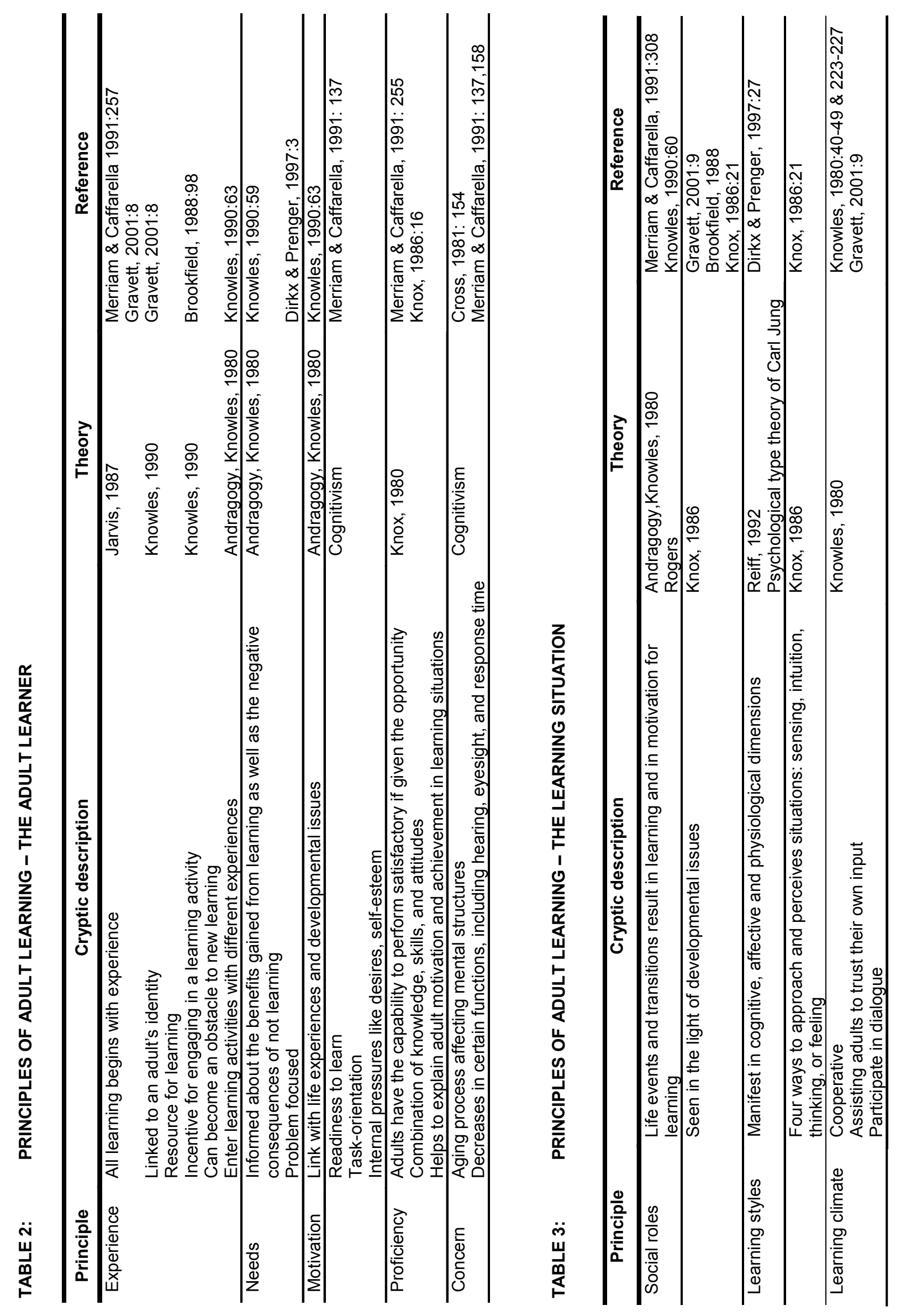


poses, according to the adult learner, the learning situation (context) and the learning process.

The adult learner

Aspects of the adult learner covered in this section are experiences, needs, motivation, proficiency, and concerns. Each aspect is introduced, summarized in Table 2, and followed by the particular implications of the indicated aspects for good practice of consumer education.

Experience The richer life experiences of the adult have been cited by nearly all writers as a key factor in differentiating adult learning form child learning. 'Adults have more experiences, adults have different kinds of experiences and adult experiences are organized differently' (Kidd, 1973, in Merriam \& Caffarella, 1991:306). Experience is a major assumption that can be viewed as a given in the literature of adult learning (Brookfield, 1988:98; Cranton, 1992:57; Dirkx \& Prenger, 1997:20). Life experiences function in several ways that are idiosyncratic to adult learning. Firstly, adult learners themselves become important resources for learning. Adults can call upon their past experiences in the formulation of learning activities, as well as applying other people's resources in a learning event. Secondly, the need to make sense out of one's life experiences is often an incentive for engaging in a learning activity in the first place. Thirdly, the actual engagement of past experiences with learning is different for adults than for children. It should also be noted that an adult's fund of past experiences can become obstacles to new learning. Some may have to unlearn negative attitudes toward learning, prejudicial views, or old ways of doing things.

The actual task to facilitate adult learners seems to be reflected in the adaptation of principles of traditional and fundamental learning theories to the characteristics of the learners. All adults bring a certain level of experience to the learning situation. It will mean that resources for learning will reside in adults themselves or at the very least, be comprehensible in terms of own experiences. An explicit connection should be made between unfamiliar concepts and the current or past experiences of learning (Brookfield, 1988:12). It is impossible to ignore learners' previous experiences - no matter what the learning situation, experience will underlie it (Cranton, 1992:58). Prominence should rather be placed on experiential techniques that tap into the experiences of the learners. Such techniques are group discussions, simulated exercises, problem-solving activities, case studies and peer-assisting activities (Knowles, 1990:59).

Negative aspects regarding experiences are that adults develop certain mental habits, biases and presuppositions that hinder them in opening their minds to new ideas and alternative ways of thinking. Facilitators in adult education should therefore try to discover ways of helping adults to examine their habits and biases and open their minds to new approaches. Sensitivity training, value clarification, meditation and dogmatism scales are among the techniques that can be used to deal with this problem (Knowles, 1990:60).

Needs Adults also frequently want to satisfy a specific need, such as preparing nutritious meals, taking care of children, or to improve household income. Adults typically bring a problem-orientation to their learning; they want to learn to address a particular problem or issue they are confronted with, and they want to use the information learnt when dealing with these problems (Dirkx \& Prenger, 1997:3). Knowles $(1990,63)$ also identifies 'orientation to learning' as one of his assumptions to adult learning. If adults perceive that learning will help them to perform certain tasks or deal with problems, they will also be more motivated to participate, bringing us to the next principle of motivation.

The facilitator must design a learning situation through which these specific needs can be satisfied. Adults must be helped to develop application strategies that can be used to solve typical problems outside the learning situation. Adults need to be informed about the benefits they will gain from learning as well as the negative consequences of not learning. The implication of this statement is that the facilitator should help the learners to become aware of the need to know certain information. A potential tool that facilitators can use is a real life or simulated experience in which the learners can discover for themselves the gaps between where they are now and where they want to be (Knowles, 1990:58).

Motivation Adults are often more motivated than children, but they easily become discouraged when they cannot connect problems they wish to solve to the content and method of learning. There is also a strong link between motivation to participate in an activity and an adult's life experiences and developmental issues. Several theories of adult learning acknowledge this link (Knowles, Knox, Mezirow, Jarvis). Motivation can therefore also be associated with 'readiness to learn', the fourth assumption of Knowles $(1990,63)$. Knowles elaborates further on the issue of motivation by stating that the most potent motivator to participate in learning activities seems to be internal pressures such as desire for satisfaction, selfesteem and to improve their quality of life (Knowles, 1990:63). These principles (referred to as motivation in this article) are also coupled with the specific needs adults have.

Adults are motivated to learn if they perceive that learning activities will help them perform certain tasks or deal with problems that they are confronted with in real life. Thus they will learn new knowledge, skills and attitudes most effectively when it is presented in the context of application to real life situations. Problems they wish to solve should be connected to the content and method of learning. Learning experiences should also be timed to coincide with particular developmental tasks. Ways to induce readiness to learn and therefore also motivation to learn, can be used by facilitation of adult education through the exposure of 
models of superior performance and simulation exercises. While it holds true that adults are responsive to some external motivators (receiving a certificate, incentive or promotion) the most potent motivators to participate in learning activities seem to be internal pressures such as a desire for job-satisfaction, selfesteem and improved quality of life (Cranton, 1989:28)

Proficiency Adults engage in learning activities mainly to enhance their proficiencies (Knox, 1986:15). Proficiency, as earlier stated, is grounded in the theory of Knox, who said an adult has the "capability to perform satisfactory if given the opportunity'. This performance, however, involves some combination of knowledge, skills, and attitudes. Proficiency-oriented adult learning emphasizes achievement of minimal standards of performance in educational tasks (Knox, 1986:16)

An understanding of discrepancies between current and desired proficiencies of adults helps to explain motives of adult learners and enables facilitators to help adults to learn more responsively and effectively. Many personality-related characteristics, such as values, interest, and self-concept affect a person's striving to enhance proficiency. Hopes and expectation for the future are major spurs to growth for adult learners. Responsiveness to such 'teachable moments' can increase the impact of an educational programme (Knox, 1986:17).

\section{Concern Older adults who have been away} from formal education for a number of years, or who have had limited opportunities for structured learning, may experience considerable anxiety in new learning situations. A frequent concern is the toll that the aging process takes on one's ability to learn. Fortunately, in recent years a growing understanding is developing about the continuous, but changed, capabilities of adults to learning into old age (Cross, 1981: 154). Without question, there are decreases in certain functions, including hearing, eyesight, and response time. The vast majority of older adults, however, compensate for such losses without drastic intervention and without noticeable impact on achievement (Merriam \& Caffarella, 1991:97, 141). Other concerns that may affect learning in adulthood are fatigue, medication, unused abilities, interference from previous learning, and environmental conditions.

The facilitator's sensitivity to older adults' slower learning rate, the need for breaks, frequent changes in tasks associated with sustained activity, low impact movement, and adjusted seating can often overcome potential difficulties. Anxieties can also be overcome through a systematic approach that leads learners without pushing them. Frequent, honest reassurance regarding learners' progress is helpful. Learning experiences that recognize and help satisfy the needs of older adults will empower them for continued participation in learning.

\section{The context}

'Learning can be powerful when it is grounded in and connected to the content and meaning of adult's lives' (Dirkx \& Prenger, 1997:19).

An adult's life situation is seen in this article as the context for learning. An adult's life is primarily defined by work and community (including family) (Merriam \& Caffarella, 1991: 305) and exists of the taking on of different social roles. Adults typically add the role of learner to other full-time occupations. Learning arises from the context of their lives, which is intimately tied to the socio-cultural setting in which they live. Contextual learning refers therefore to learning that adults find meaningful, relevant and significant to their situations and life experiences (Shor, 1992, in Dirkx \& Prenger, 1997:19).

Features of the learning situation dealt with in this section are social roles, learning styles and the learning climate that may influence the learning situation. Again, each aspect will be discussed first, summarized (see Table 3 ), after which the particular implications of the mentioned aspects for the good practice of consumer education are discussed.

Social roles The social roles adults fulfil are seen in the light of developmental issues that adults deal with. These issues are usually task-related bringing up children, managing a home, surviving a marriage, achieving social responsibilities, and changing jobs. In addition, adults face many life events and transitions that require adjustments, which they cope with by engaging in systematic learning activities. According to Merriam and Caffarella (1991:308) it is these life events and adjustments that result in significant, meaningful learning and in motivation for learning. These events in an adult's life (typically referred to as teachable moments), heightens readiness to learn and often trigger participation in educational activities (Knowles, 1975:46; Knox, 1986:21).

Learning styles Learning styles among adult learners can also be considered a contextual variable, because it reflects what the learner brings to a particular learning experience (Dirkx \& Prenger, 1997:27). Learning styles are described as overall patterns that provide direction to learning and teaching. Learning styles can also be described as a set of factors, behaviors, and attitudes that facilitate learning for an individual in a given situation...the styles may be unique to the task, or it may duplicate a previous experience (Cranton, 1989:30; Cranton, 1992:40; Merriam \& Caffarella, 1991:176; Reiff, 1992 in Dirkx \& Prenger, 1997:27).

Intelligence, age, formal education, and previous specialized experience all contribute to the variety of learning styles that are found (Knox, 1986:21). Jung (in Dirkx \& Prenger, 1997:29) identifies four particular styles, namely sensing, intuition, thinking and feeling. Sensing refers to seeing the world in concrete and real terms, using the senses to gather information and 
to learn new things. Intuitive learning types like to imagine, invent and solve problems. These people are also more global in their orientation to learning tasks. Adults with a thinking style will be more objective when making decisions, with an emphasis on fairness and logical procedures. Learners of the feeling type will often put emphasis on the subjective and emotional components of a learning situation and will base decisions on insight and emotions.

Understanding the different events happening in an adult's life can help facilitators to offer educational activities that are responsive to those developmental tasks and to select relevant and helpful educational materials and activities (Knox, 1986: 21). Familiarity with participants' preferred learning styles can be used to provide varied learning activities that enable them to select preferred methods and broaden the ways in which they learn effectively. Taking learning styles into account can help to motivate learners, to improve their self-concepts, and to increase achievement. It can also lead to diverse ways of learning and flexibility among learners. Communication is enhanced when different learning styles are incorporated into the learning setting. Facilitators should also avoid judging learners because of their particular preference or approaches to learning (Cranton, 1992:32; Dirkx \& Prenger, 1997:27; Knox, 1986: 21).

Learning climate Everyone involved in the learning process interacts to shape the form and process of the learning experience (Brookfield, 1988:277). So do the structural factors of the institution itself, such as facilities, the organization's mission, and its operating procedures. Every organization has a culture, a system of shared beliefs and understandings - that interact with people and structures and produce different learning situations or contexts. These factors can also be referred to as the learning climate. An attempt to discuss all these factors would be an enterprise well outside the scope of this article. The facilitator of adult education, however, needs to be aware of these factors and more specifically the implication they will have in practice. This implication will be discussed later.

A climate conducive to learning should be established. This learning climate should be one in which adults feel at ease - informally arranged and decorated, with sufficient light and good acoustics. Acceptance, respect, and support, freedom of speech without fear of ridicule will enhance learning (Knowles, 1980:45-49).

\section{The learning process}

'Wanting to learn is the greatest aid to learning' (Merriam \& Caffarella, 1991:310).

The separation of cognitive factors and non-cognitive factors inherent to learning ability has lead to a better understanding of the adult learning process (Merriam \& Caffarella, 1991:309). Non-cognitive factors are either related to the adult learner (such as motivation) or the learning situation (such as the learning climate) whereas the cognitive part of learning belongs to the learning process (such as the construction of meaning). The learning process also involves activities such as interaction, participation, liberation, selfdirectedness and certain responses (Table 4).

Within the particular theory of constructivism new learning is seen as being constructed through the learner's existing knowledge, serving as an interpretative framework to internalize new information. The construction process can be individual but often occurs through social interaction (Gravett, 2001:20). It can therefore be said that the construction of meaning during adulthood as part of the learning process includes internal cognitive activity and social interaction (Merriam \& Caffarella, 1991:256).

\section{Cognitive activity The concept of cognitive} activity brings us back to the principles of cognitive theory. Adults acquire, process, store and retrieve information in an individual but specific way, differing from that of children. The emphasis during adult education is on the quality of information rather than quantitative amounts of information (Merriam \& Caffarella, 1991:182). Beyond the traditional work of Piaget (1972) the notion of the 'dialectic nature of mature adult thought' also appears (Kramer, 1983, 1989; Riegel, 1973, 1976 in Merriam \& Caffarella, 1991:183). According to Kramer (1989, in Merriam \& Caffarella, 1991:183) 'dialectical thought is characterized by an awareness that all thought processes are culturally and historically bound and therefore dynamic and constantly evolving'.

Interaction The term 'active learning' also surfaces when discussing the learning process, referring to what students are doing within the learning process. When adults are active, they are engaged in problem solving, doing things and thinking about what they are doing. The facilitator only acts as a 'guide on the side' rather than as a 'sage on the stage' (Dirkx \& Prenger, 1997:22,24). This principle can also be referred to as 'interaction', with other learners and also with the learning content.

Participation Adults engage in adult learning as a result of there own volition (Brookfield, 1988 in Jones, 1988:156). Adults' willingness to learn also means that they are less likely to resist participatory learning techniques such as discussion, role-playing, games, small-group work, and collaborative analysis of personal experiences. Learners however, can also easily withdraw participation if they feel that the activity does not meet their needs, does not make any particular sense or is conducted at a level that is incomprehensible to them (Brookfield, 1988:11).

Liberation The concept of liberation refers to the empowerment of the learner. The facilitator attempts also to become a learner, trying to understand and listen to the needs of the learner. The facilitator and learner are thus mutually responsible for the learning process (Cranton, 1989:6). Aspects of praxis (action and reflection) as well as critical thinking also 


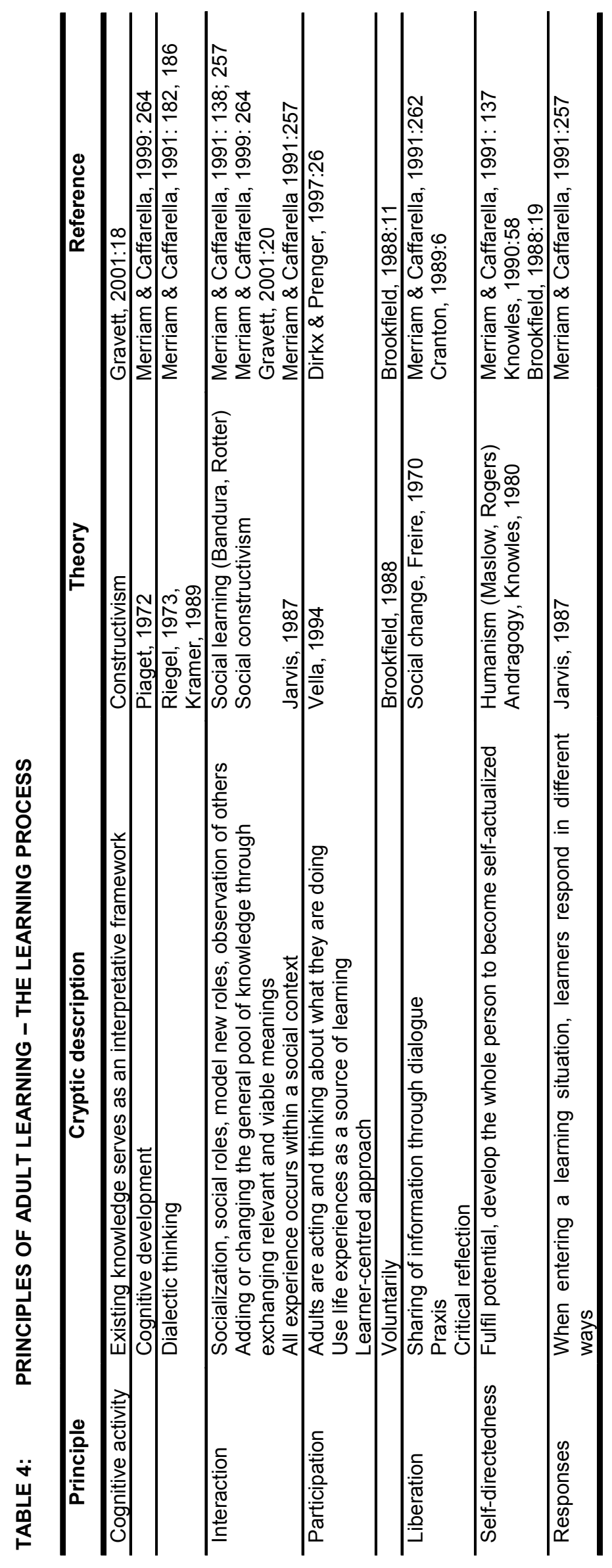


relate. Adults will be more fully developed when a spirit of critical reflection is fostered.

\section{Self-directedness Emphasis on self-directed} learning enables learners to gain mastery, selfesteem and confident use of learning material and procedures (Cross, 1981:187; Rinke, 1985, in Knox, 1986:26). At the heart of self-directedness is the adult's assumption of control over setting goals and generating meaningful evaluative criteria. Selfdirected learning in adulthood is not merely a manner of applying techniques of independent study it is, rather, a paradigm shift, replacing the way adults interpreted their worlds with alternative ways of thinking, and behaving (Brookfield, 1988:19). Selfdirectedness is not a characteristic of adult learners. It can rather be seen as a process of voluntarily engaging in a learning experience (Cranton, 1992:55).

The practical implication of this principle is that facilitators should present to learners alternative ways of thinking and behaving, in order to assist them to reflect critically on their assumptions and try to imagine alternatives. It is also important to note that many adults show a 'marked disinclination to behave in anything approaching a self-directed manner' (Brookfield, 1988:26). In such cases the facilitator should assist the learner to progressively decrease dependency on the facilitator and to assume responsibility for his/her own learning (Suanmali, 1981, in Brookfield, 1988:36). A combination of group and individual self-directed learning techniques will most likely also foster creative and critical thinking, further contributing to effective adult learning.

Responses When a learner enters a particular learning situation, he/she may respond in different ways, namely to (be):

- Presumptuous (presuming that learning methods that has worked before will work again)

- Non-considerate (being too preoccupied to consider a response)

- Reject the opportunity to learn

- Preconscious (unconsciously internalizing something)

- Practice a new skill until it is learned

- Memorize in so far that the information can be reproduced again later

- Reflective (practice problem-solving)

- Take part in experiential learning (result of experimenting upon the environment).

- These responses form a hierarchy; the first three not resulting in learning at all, the second three being non-reflective learning, while definite reflective learning takes place within the last three responses. These responses also encompass multiple types of learning and its different outcomes (Merriam \& Caffarella (1991:257).

A particular way of construction of meaning is neither inherently good nor bad, but can rather be seen as unique for different people at specified points in time. Facilitators should therefore not attempt to predict how learners are likely to perform typical tasks such as remembering, focusing, reflecting and analyzing information. Cognition and the construction of meaning are more than internal psychological processes. Facilitators should also 'consider the impact of the family, the educational systems and the culture on what we know and how we come to know it' (Merriam \& Caffarella, 1991:178).

\section{CONCLUSION}

'Effective teaching depends on being responsive to the learners in the program, not to adults in general' (Knox, 1986:38).

One cannot take all these principles into account when practicing adult education. Facilitators simply do not have the time and expertise to grasp all the learners' unique backgrounds and aspirations. Effective facilitators recognize and understand that there are some general principles and philosophical perspectives associated with adult learning that can enable them to be especially helpful to learners in each context and can give direction to programme development (Knox, 1986:15; Maehl, 2000:34). Facilitating the adult learning process relies on being perceptive and flexible, asking questions and listening to the answers and of being prepared to change plans. There can be no set of rules that will take the facilitator through the process. If a general rule were to be stated, it would be that a variety of methods and materials should be planned so that different individuals with different preferences and abilities would feel satisfied with some aspects of the learning situation (Cranton, 1992:35).

\section{REFERENCE LIST}

BROOKFIELD, SD. 1988. Understanding and facilitating adult learning. London. Jossey-Bass.

CAFFARELLA, RS. 1994. Planning programs for adult learners. A practical guide for educators, trainers and staff developers. San Francisco. JosseyBass.

CRANTON, P. 1989. Planning instruction for adult learners. Toronto. Wall \& Thompson.

CRANTON, P. 1992. Working with adults. Toronto. Wall \& Emerson.

CROSS, KP. 1981. Adults as learners. Increasing participation and facilitating learning. San Francisco. Jossey-Bass.

DIRKX, JM \& PRENGER, M. 1997. A guide for planning and implementing instruction for adults. A theme-

based approach. San Francisco. Jossey-Bass. GAGNON, GW \& COLLAY, M. Constructivist Learning Design. [WwW document - 2/8/2002]. www.prainbow.com/cld/cldp.htm

GRAVETT, S. 2001. Adult learning. Designing and implementing learning events. A dialogic approach. Pretoria. Van Schaik.

JONES, D. 1988. Adult education and cultural development. London. Routledge.

KNOWLES, MS. 1980. The modern practice of adult education. Revised edition. Chicago. Association Press.

KNOWLES, MS. 1990. The adult learner. A neglected species. 4th ed. London. Gulf.

KNOX, AB. 1986. Helping adults learn. San Francisco. Jossey-Bass.

MAEHL, WH. 2000. Lifelong learning at its best. Innovative Practices in Adult Credit Programs. San Francisco. Jossey-Bass.

MERRIAM, SB \& CAFFARELLA, RS. 1991. Learning in adulthood. A comprehensive guide. San Francisco. Oxford.

MERRIAM, SB \& CAFFARELLA, RS. 1999. Learning in adulthood. A comprehensive guide. 2nd ed. San Francisco. Jossey-Bass 